\section{New initiative for sturgeon}

In an editorial I wrote for this page in $1984 \mathrm{I}$ questioned the cost-effectiveness of using consumer boycotts as a conservation tool. I argued that, although they could be effective and provided two examples of where they had been - they were costly, they often only acted to salve the consciences of a few people, and did not tackle the fundamental problems of unsustainable use of resources. To do that political action was what was needed.

However, there is no doubt that when consumer demand is threatening the survival of species and when the political efforts to tackle the problem at source are lacking or slow to move, then taking action at the consumer end of the chain is often the only way to take conservation action. But rather than persuade the consumer to stop buying products of endangered species it may be more effective to target the sellers.

In a new initiative announced at the Species Survival Commission (SSC) meeting, which preceded the World Conservation Congress in Montreal in October, the SSC is collaborating with IUCN's Environmental Law Commission in taking such action to help save sturgeon species from extinction. Nicholas Robinson of Pace University Environmental Law Centre, White Plains, New York, USA (and Deputy Chair of the IUCN's Commission on Environmental Law) is working with Vadim Birstein (Chair, IUCN/SSC Sturgeon Specialist Group) to draft New York State legislation to make it illegal to sell the caviar of threatened species and to require the species of caviar being sold to be identified by genetic testing. New York State passed and successfully implemented, similar legislation in the 1970 s to stop the sale of furs from endangered cat species and in the 1980s to ban the sale of wild-caught birds. With caviar sales booming in the major cities of the world, the action in New York - planned to coincide with the peak of caviar sales at Christmas - will only deal with a small part of the problem but it will serve to raise awareness of its severity and will act as a model to be copied elsewhere.

All sturgeon species are in deep trouble, especially those that are killed for caviar. The growing demand for the booming international caviar market has stimulated uncontrolled over-fishing and poaching of the main commercial species in the Volga RiverCaspian Sea Basin (the beluga Huso huso, Russian sturgeon Acipenser guldenstaedti and stellate sturgeon $A$. stellatus) and in the Russian Far East and China (the kaluga Huso dauricus and the Amur river sturgeon $A$. schrencki). The beluga is the most vulnerable to overfishing: dam construction has caused the loss of most of its natural spawning sites and in the last few years it has not been restocked artificially in Russia because of lack of wild breeding stock. The declines in commercial sturgeon species have increased the harvest of species that had not previously been exploited commercially, including the Siberian sturgeon $A$. baerii, which is now extremely threatened by poaching in the $\mathrm{Ob}$ River basin.

The Sturgeon Specialist Group evaluated the status of 25 sturgeon and two related paddlefish species using the new IUCN categories for the 1996 Red List of Threatened Animals. All were found to be threatened, with six of them critically endangered and 11 endangered.

The New York initiative hopes to buy time for the beluga while proposals are prepared for listing all sturgeon species on Appendix II of the Convention on Trade in Endangered Species (CITES) at its meeting in June 1997. A number of other initiatives are under way to help sturgeon species in various parts of their ranges. The Europe-based Society to Save the Sturgeon aims to restore Acipensor sturio in western Europe and USA's Kentucky State University is negotiating with Chinese authorities on a breeding programme for the Chinese paddlefish Psephurus gladius.

The most serious threat of all, however, is the massive poaching and illegal trade, which is controlled by notorious criminal groups in Russia. It is hoped that the controls that will be brought about by CITES listing and other actions to stem the demand at the consumer end of the chain will help Russian authorities to take action at the source.

Jacqui Morris, Editor 